\title{
Peramalan Jumlah Penumpang dan Barang di Bandar Udara Internasional Juanda dan Pelabuhan Tanjung Perak Menggunakan Model Hybrid ARIMAX dan Deep Learning Neural Networks
}

\author{
(1) Bella Puspa Dewani, ${ }^{(2)}$ Suhartono, ${ }^{(3)}$ Muhammad Sjahid Akbar \\ ${ }^{(1)(2)(3)}$ Departemen Statistika, Fakultas Matematika, Komputasi, dan Sains Data, \\ Institut Teknologi Sepuluh Nopember (ITS) \\ Jl. Arief Rahman Hakim, Surabaya 60111 Indonesia \\ e-mail: ${ }^{(1)}$ belladewani@gmail.com ${ }^{(2)}$ suhartono@statistika.its.ac.id ${ }^{(3)} \mathrm{m} \_$sjahid_a@statistika.its.ac.id
}

\begin{abstract}
Abstrak-Arus penumpang dan barang di Bandar Udara Internasional Juanda dan Pelabuhan Tanjung Perak cenderung fluktuatif dan tidak menentu. Oleh karena itu diperlukan pengetahuan akan keadaan arus penumpang dan barang di masa depan, agar pengembangan yang dilakukan tepat dan berguna. Penelitian ini dilakukan bertujuan untuk memodelkan serta mendapatkan peramalan mengenai jumlah penumpang dan barang di Bandar Udara Internasional Juanda dan Pelabuhan Tanjung Perak dengan membandingkan 5 model. Model tersebut antara lain model ARIMAX, model FFNN, model DLNN dengan 2 hidden layer, model hybrid ARIMAX-FFNN dan model hybrid ARIMAX-DLNN untuk mendapatkan hasil peramalan terbaik. Data yang digunakan dalam penelitian ini merupakan data sekunder yang diperoleh dari Badan Pusat Statistika (BPS). Data yang digunakan adalah data bulanan mulai Januari 2001 hingga Desember 2017 untuk Bandar Udara Internasional Juanda, sedangkan Pelabuhan Tanjung Perak mulai Januari 2006. Hasil penelitian menunjukkan model hybrid ARIMAX-DLNN memiliki kemampuan yang baik untuk menangkap pola data yang beragam dan menghasilkan ramalan yang baik pada data training. Hal tersebut dilihat dari nilai RMSEP yang lebih kecil dibandingkan dengan model lainnya. Namun model DLNN memiliki kemampuan yang baik dalam meramalkan data testing. Model terbaik untuk 8 variabel yang digunakan, terdapat 7 variabel dengan model terbaik yaitu model DLNN, sedangkan sisanya model hybrid ARIMAX-DLNN.

Kata kunci-ARIMAX, Barang, Deep Learning Neural Networks, Feed Forward Neural Networks, Hybrid, Penumpang
\end{abstract}

\section{PENDAHULUAN}

$\mathrm{T}$ ransportasi berfungsi sebagai sarana bagi manusia atau barang untuk dapat berpindah dari suatu tempat ke tempat lain secara efisien setiap waktu untuk mendukung aktivitas manusia dan telah menjadi kebutuhan dasar masyarakat. Bandar Udara Internasional Juanda merupakan salah satu bandara tersibuk di Indonesia. Bandara tersebut memiliki trafik pergerakan pesawat tertinggi kedua di Indonesia yang melayani 148,73 ribu pergerakan pesawat atau meningkat 0,09 persen jika dibandingkan dengan tahun sebelumnya yang mencapai 148,59 ribu pergerakan pesawat. Selain itu, trafik kargo tertinggi kedua di Indonesia juga terjadi di Bandar Udara Internasional Juanda [1]. Pelabuhan Tanjung Perak merupakan pelabuhan yang menjadi gerbang utama arus logistik ke Indonesia bagian timur. Pelabuhan tersebut melayani rute pelayaran domestik dan juga melayani bongkar muat peti kemas ekspor impor [2]. Aktivitas Pelabuhan Tanjung Perak yang padat, tak hanya arus penumpang, proses bongkar muat membuat dwelling time sepanjang tahun 2017 untuk jalur merah 8,09 hari dan untuk jalur hijau 3,96 hari. Pemerintah telah melakukan berbagai usaha untuk menurunkan dwelling time tersebut [3].

Arus penumpang dan barang di Bandar Udara Internasional Juanda dan Pelabuhan Tanjung Perak cenderung fluktuatif dan tidak menentu. Oleh karena itu diperlukan pengetahuan akan keadaan arus penumpang dan barang di masa depan, agar pengembangan yang dilakukan tepat dan berguna. Salah satu cara mengetahui arus penumpang dan barang di Bandar Udara Internasional Juanda dan Pelabuhan Tanjung Perak adalah dengan menggunakan forecasting. Huda, Kuswanto, dan Suhartono telah melakukan penelitian berupa peramalan jumlah frekuensi penumpang pesawat terbang domestik di Bandar Udara Internasional Juanda dengan menggunakan metode ARIMA dan Fungsi Transfer dengan hasil bahwa model terbaik untuk meramalkan jumlah frekuensi penumpang pesawat terbang domestik adalah model ARIMA [4].

ARIMA dan Artificial Neural Networks (ANN) dapat dikombinasikan menjadi bentuk model hybrid untuk mendapatkan performa peramalan yang lebih baik seperti yang dilakukan oleh Zhang, dimana model hybrid sangat efektif untuk meningkatkan akurasi dalam prediksi dibandingkan dengan model ARIMA atau ANN secara terpisah [5]. Model hybrid memiliki kemampuan yang baik dalam menangkap pola linier melalui model ARIMA dan menangkap pola nonlinier melalui ANN. Selain hybrid ARIMA-ANN, model hybrid ARIMA dan Deep Learning Neural Networks (DLNN) untuk memprediksi telah dilakukan oleh Hirata dkk. dimana DLNN merupakan ANN dengan jumlah hidden layer lebih dari satu [6]. Penelitian menggunakan DLNN dalam time series telah banyak dilakukan, antara lain penelitian dari Zhu dkk. yang melakukan prediksi jarak pandang dalam Bandar Udara Internasional Urumqi menggunakan DLNN [7], selain itu He melakukan penelitian berupa prediksi beban listrik menggunakan DLNN [8], dan penelitian dari Lv dkk. melakukan prediksi arus lalu lintas dengan big data dengan pendekatan DLNN [9]. Namun tidak selalu model kompleks mampu menghasilkan akurasi yang baik. Hal tersebut seperti yang dinyatakan Makridakis dan Hibon 
dalam Kompetisi M3, dimana model kompleks tidak selalu meningkatkan akurasi dan lebih baik dibandingkan model sederhana [10]. Oleh karena itu diperlukan perbandingan metode untuk mendapatkan ramalan terbaik. Perbandingan metode tersebut telah dilakukan oleh Makridakis dkk. dalam Kompetisi M3 serta Kompetisi M4 [10,11].

Penelitian ini dilakukan peramalan mengenai jumlah penumpang dan barang di Bandar Udara Internasional Juanda dan Pelabuhan Tanjung Perak dengan membandingkan 5 model, yaitu model ARIMAX, model Feed Forward Neural Networks (FFNN), model DLNN dengan 2 hidden layer, model hybrid ARIMAX-FFNN dan model hybrid ARIMAX-DLNN untuk mendapatkan hasil ramalan terbaik. Diharapkan hasil penelitian berupa informasi prediksi jumlah penumpang dan barang di Bandar Udara Internasional Juanda dan Pelabuhan Tanjung Perak dapat membantu pemerintah dalam melakukan pengembangan Bandar Udara Internasional Juanda dan Pelabuhan Tanjung Perak.

\section{TINJAUAN PUSTAKA}

A. Autoregressive Integrated Moving Average with Exogeneus Variable (ARIMAX)

Model ARIMAX merupakan model ARIMA dengan penambahan variabel eksogen atau variabel $X$ [12]. Variabel eksogen tersebut dapat berupa metrics yang merupakan data dengan skala interval dan rasio, serta non metrics yaitu data dengan skala nominal dan ordinal yang dapat dijadikan variabel dummy dalam model regresi. Model ARIMAX ini memiliki kemiripan bentuk dengan regresi linier yang memiliki variabel tambahan, seperti variasi kalender. Model yang didapatkan dalam pemodelan ARIMAX secara umum sebagai berikut:

$Z_{t}=\beta_{0}+\beta_{1} X_{1, t}+\ldots+\beta_{g} X_{g, t}+\frac{\theta_{q}(B) \Theta_{Q}\left(B^{S}\right)}{\phi_{p}(B) \Phi_{P}\left(B^{S}\right)(1-B)^{d}\left(1-B^{S}\right)^{D}} \varepsilon_{t}$,

dalam hal ini $\mathrm{Xi}, \mathrm{t}$ dapat berupa variabel yang mewakili komponen tren, musiman, variasi kalender atau variabel prediktor lainnya. Data dengan variasi kalender dapat dimodelkan menggunakan model regresi linier sebagai berikut:

$$
Z_{t}=\beta_{0}+\beta_{1} V_{1, t}+\ldots+\beta_{p} V_{p, t}+\varepsilon_{t},
$$

dimana $V_{p, t}$ adalah variabel dummy untuk $p$ efek variasi kalender. Jumlah dari efek variasi kalender dapat diidentifikasi berdasarkan pada plot time series pada data [13].

\section{B. Neural Networks (NN)}

Model Neural Networks merupakan salah satu contoh model nonlinear yang mempunyai bentuk fungsional fleksibel dan mengandung beberapa parameter yang tidak dapat diinterpretasikan seperti pada model parametrik. Pada dasarnya, NN merupakan suatu kumpulan dari elemen-elemen pemroses yang saling berhubungan, yang disebut dengan unit-unit atau syaraf-syaraf [14]. Bentuk arsitektur NN yang secara umum paling banyak digunakan dalam aplikasi bidang teknik atau rekayasa adalah Multi Layer Perceptrons (MLP) yang juga dikenal dengan FFNN. Dalam pemodelan statistik, FFNN dapat dipandang sebagai suatu kelas yang fleksibel dari fungsi-fungsi nonlinear. Gambar 1 adalah suatu contoh dari bentuk khusus FFNN dengan satu lapis tersembunyi yang lebih dikenal dengan FFNN dengan satu lapis tersembunyi yang terdiri dari $q$ unit neuron dan lapis output yang hanya terdiri dari satu unit neuron. Dalam arsitektur ini, nilai-nilai respon atau output $\hat{y}$ dihitung dengan

$$
\hat{Z}_{(k)}=f^{o}\left[\sum_{j=1}^{q}\left[w_{j}^{o} f_{j}^{h}\left(\sum_{i=1}^{p} w_{j i}^{h} X_{i(k)}+b_{j}^{h}\right)+b^{o}\right]\right],
$$

dengan:

$X_{i(k)}=$ variabel input sebanyak $p,(i=1,2, \ldots, p)$

$\hat{Z}_{(k)}=$ nilai dugaan dari variabel output

$k=$ indeks pasangan data input-target $\left(x_{i(k)}, y_{(k)}\right), k=$ $1,2, \ldots, n$

$w_{j i}^{h}=$ bobot dari input ke- $i$ yang menuju neuron ke-j pada lapis tersembunyi, dengan $j=1,2, \ldots, q$

$b_{j}^{o} \quad=$ bias pada neuron ke-j pada lapis tersembunyi dengan $(j=1,2, \ldots, q)$

$f_{q}^{h}=$ fungsi aktifasi di neuron ke-j pada lapis tersembunyi

$w_{j}^{o}=$ bobot dari neuron ke-j di lapis tersembunyi yang menuju neuron pada lapis output

$b^{o} \quad$ = bias pada neuron di lapis output

$f^{o} \quad$ fungsi aktifasi pada neuron di lapis output.

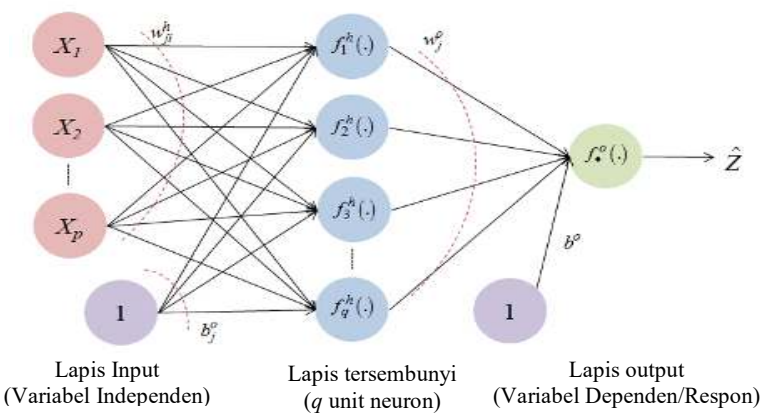

Gambar 1. Arsitektur FFNN dengan satu lapis tersembunyi, $p$ unit input, $q$ unit neuron di lapis tersembunyi, dan satu unit neuron output.

\section{Deep Learning Neural Networks (DLNN)}

Deep LearningNeural Networks (DLNN) merupakan Feed Forward Neural Networks (FFNN) dengan jumlah hidden layer lebih dari satu. Pada model time series, hubungan antara output $\left(Z_{t}\right)$ dan input $\left(Z_{t-1}, Z_{t-2}, \ldots, Z_{t-p}\right)$ dalam model DLNN dengan dua hidden layer dijelaskan dengan:

$\hat{Z}_{(k)}=f^{o}\left[\sum_{i=1}^{s} \alpha_{i} f_{i}^{h_{2}}\left(\sum_{j=1}^{r} \beta_{i j} f_{j}^{h_{1}}\left(\sum_{k=1}^{p} \gamma_{i k} X_{i(k)}+b_{j}^{h_{1}}\right)+b_{i}^{h_{2}}\right)+b^{o}\right]+\varepsilon_{t},{ }^{(4)}$

dengan

$X_{i(k)}=$ variabel input $\operatorname{sebanyak} p,(k=1,2, \ldots, p)$

$\hat{Z}_{(k)} \quad=$ nilai dugaan dari variabel output

$k \quad=$ indeks pasangan data input-target $\left(x_{i(k)}, z_{(k)}\right)$, $k=1,2, \ldots, n$

$\gamma_{i j}=$ bobot dari input ke- $i$ yang menuju neuron ke- $j$ pada lapis tersembunyi pertama dengan $j=$ $1,2, \ldots, r$ 
$\beta_{i j}=$ bobot dari neuron ke- $j$ pada lapis tersembunyi pertama yang menuju neuron ke- $i$ pada lapis tersembunyi kedua $(i=1,2, \ldots, s)$

$\alpha_{i} \quad=$ bobot dari neuron ke- $i$ di lapis tersembunyi kedua yang menuju neuron pada lapis output

$b_{j}^{h_{1}}=$ bias pada neuron ke- $j$ pada lapis tersembunyi pertama

$b_{i}^{h_{2}} \quad=$ bias pada neuron ke- $i$ pada lapis tersembunyi kedua

$b^{o} \quad=$ bias pada neuron di lapis output

$f_{j}^{h_{1}} \quad=$ fungsi aktifasi di neuron ke-j pada lapis tersembunyi pertama

$f_{i}^{h_{2}}=$ fungsi aktifasi di neuron ke- $i$ pada lapis tersembunyi kedua

$f^{o} \quad$ = fungsi aktifasi pada neuron di lapis output.

Sedangkan arsitektur DLNN dengan jumlah hidden layer sebanyak dua pada Gambar 2 sebagai berikut:

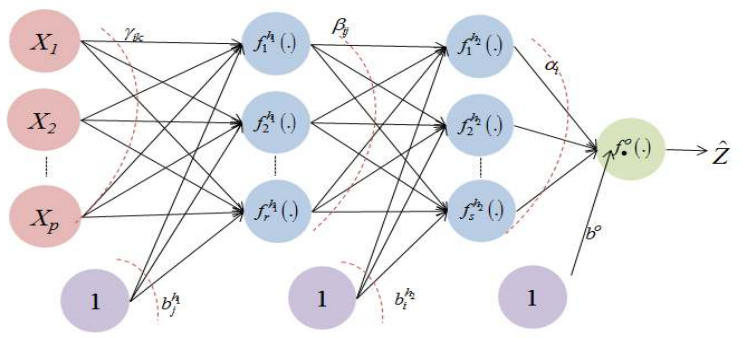

Lapis Input Lapis tersembunyi

Lapis output (Variabel Independen) (Variabel Dependen/Respon)

Gambar 2 Arsitektur DLNN dengan dua lapis tersembunyi, $p$ unit input dan satu unit neuron output

\section{Model Hybrid ARIMAX-DLNN}

Model ARIMAX dan DLNN telah mampu dalam menangkap pola linier dan nonlinier pada masing-masing model. Namun, tidak semua model universal sesuai untuk segala permasalahan. Tidak mudah untuk mengetahui sepenuhnya karakteristik suatu data, namun metode hybrid yang dapat menangkap pola linier dan nonlinier merupakan suatu strategi yang baik untuk dilakukan. Model time series berikut terdiri dari komponen linier dan komponen nonlinier [5], yaitu:

$$
Z_{t}=L_{t}+N_{t},
$$

dengan $L_{t}$ merupakan komponen linier dan $N_{t}$ merupakan komponen nonlinier yang dilakukan estimasi dari data. Pertama, ARIMAX akan memodelkan komponen linier, kemudian residual data hanya akan berisi komponen nonlinier. Residual pada model linier di waktu ke- $t$, yaitu $e_{t}$ didapatkan sebagai berikut:

$$
e_{t}=Z_{t}-\hat{L}_{t},
$$

dengan $\hat{L}_{t}$ merupakan nilai prediksi pada waktu ke-t yang didapatkan dari proses ARIMAX. Nilai residual sangat penting karena masih terdapat korelasi linear antar residual, sehingga model linier tidaklah cukup. Pemodelan nilai residual dengan DLNN korelasi nonlinier tersebut dapat dideteksi. Model DLNN dari nilai residual sebagai berikut:

$$
e_{t}=f\left(e_{t-1}, e_{t-2}, \ldots, e_{t-n}\right)+\varepsilon_{t},
$$

dengan $f$ merupakan fungsi nonlinier yang didapatkan dari DLNN dan $\varepsilon_{t}$ merupakan random error. Jika $\hat{N}_{t}$ hasil dari perhitungan $f$ diatas, maka nilai prediksi dapatkan dari persamaan sebagai berikut:

$$
\hat{Z}_{t}=\hat{L}_{t}+\hat{N}_{t} \text {. }
$$

\section{E. Pemilihan Model Terbaik}

Pemilihan model terbaik pada penelitian ini menggunakan kriteria kesalahan peramalan Root Mean Square Error (RMSE) dan Mean Average Percentage Error (MAPE) untuk data in sample, sedangkan untuk data out sample menggunakan Root Mean Square Error Prediction (RMSEP) dan Mean Average Percentage Error Prediction (MAPEP) untuk data out sample. Rumus RMSE dan RMSEP sebagai berikut [13]:

RMSE $=\sqrt{\frac{\sum_{t=1}^{n}\left(Z_{t}-\hat{Z}_{t}\right)^{2}}{n},}$
RMSEP $=\sqrt{\frac{\sum_{l=1}^{L}\left(Z_{n+l}-\hat{Z}_{n}(l)\right)^{2}}{L},}$

dengan

$Z_{t} \quad=$ data in sample,

$\hat{Z}_{t} \quad=$ nilai fits,

$Z_{n+l}=$ data out sample,

$\hat{Z}_{n}(l)=$ nilai ramalan,

$n \quad=$ jumlah data in sample,

$L \quad=$ jumlah data out sample.

MAPE dan MAPEP digunakan untuk mengetahui rata-rata harga mutlak dari persentase kesalahan tiap model. Rumus MAPE dan MAPEP sebagai berikut [13]:

$$
\begin{aligned}
& \text { MAPE }=\frac{1}{n} \sum_{t=1}^{n}\left|\frac{Z_{t}-\hat{Z}_{t}}{Z_{t}}\right| \times 100 \%, \\
& \text { MAPEP }=\frac{1}{L} \sum_{l=1}^{L}\left|\frac{Z_{n+l}-\hat{Z}_{n}(l)}{Z_{n+l}}\right| \times 100 \% .
\end{aligned}
$$

\section{METODOLOGI PENELITIAN}

\section{A. Sumber Data}

Data yang digunakan merupakan data sekunder yang diperoleh dari Badan Pusat Statistika (BPS). Data yang digunakan adalah data bulanan mulai Januari 2001 hingga Desember 2017 untuk Bandar Udara Internasional Juanda, sedangkan Pelabuhan Tanjung Perak mulai Januari 2006. Data penelitian tersebut dibagi menjadi data training yaitu Januari 2001 hingga Desember 2016 untuk Bandar Udara Internasional Juanda, sedangkan Pelabuhan Tanjung Perak mulai Januari 2006. Data testing yaitu Januari 2017 hingga Desember 2017. Data yang didapatkan merupakan statistik sektoral yang diselenggarakan oleh Bandar Udara Internasional Juanda dan Pelabuhan Tanjung Perak.

\section{B. Variabel Penelitian}

Variabel yang digunakan dalam penelitian ini dapat dilihat pada Tabel 1. 
Tabel 1. Variabel Penelitian

\begin{tabular}{ll}
\hline Variabel & \multicolumn{1}{c}{ Keterangan } \\
\hline$Z_{1, t}$ & $\begin{array}{l}\text { Jumlah penumpang keberangkatan domestik pada } \\
\text { bulan ke- } t \text { di Bandara Juanda }\end{array}$ \\
$Z_{2, t}$ & $\begin{array}{l}\text { Jumlah penumpang keberangkatan internasional } \\
\text { pada bulan ke- } t \text { di Bandara Juanda }\end{array}$ \\
$Z_{3, t}$ & $\begin{array}{l}\text { Jumlah barang yang dimuat pada penerbangan } \\
\text { domestik bulan ke- } t \text { di Bandara Juanda }\end{array}$ \\
$Z_{4, t}$ & $\begin{array}{l}\text { Jumlah barang yang dimuat pada penerbangan } \\
\text { internasional bulan ke- } t \text { di Bandara Juanda }\end{array}$ \\
$Z_{5, t}$ & $\begin{array}{l}\text { Jumlah penumpang keberangkatan dalam negeri } \\
\text { pada bulan ke- } t \text { di Pelabuhan Tanjung Perak }\end{array}$ \\
$Z_{6, t}$ & $\begin{array}{l}\text { Jumlah penumpang kedatangan dalam negeri pada } \\
\text { bulan ke- } t \text { di Pelabuhan Tanjung Perak }\end{array}$ \\
$Z_{7, t}$ & $\begin{array}{l}\text { Jumlah barang dalam negeri yang dibongkar pada } \\
\text { bulan ke- } t \text { di Pelabuhan Tanjung Perak }\end{array}$ \\
$Z_{8, t}$ & $\begin{array}{l}\text { Jumlah barang dalam negeri yang dimuat pada } \\
\text { bulan ke- } t \text { di Pelabuhan Tanjung Perak }\end{array}$ \\
\hline
\end{tabular}

C. Langkah Analisis

Langkah analisis yang dilakukan dalam penelitian ini sebagai berikut:

1. Melakukan pemodelan ARIMAX (selanjutnya dinotasikan M-1) dengan menggunakan regresi time series sebagai berikut:

a. Menentukan variabel dummy untuk komponen tren, musiman dan variasi kalender.

b. Mendapatkan nilai residual dengan melakukan pemodelan regresi time series.

c. Memodelkan residual hasil regresi time series dengan menggunakan metode ARIMA.

d. Melakukan pemodelan menggunakan ARIMAX, dengan model umum seperti pada Persamaan (1)

e. Memilih model ARIMAX terbaik.

f. Melakukan peramalan dengan model ARIMAX terbaik.

2. Melakukan pengujian linieritas.

3. Melakukan pemodelan FFNN (selanjutnya dinotasikan M-2) dan DLNN (selanjutnya dinotasikan M-3) sebagai berikut:

a. Menentukan variabel input yang akan digunakan, yaitu komponen pada model ARIMAX terbaik seperti pada Langkah 2.

b. Melakukan preprocessing pada jumlah penumpang dan barang menggunakan normalisasi $[0,1]$.

c. Menentukan banyaknya neuron, yaitu dari 1 hingga 10 neuron pada masing-masing hidden layer.

d. Melakukan estimasi parameter untuk pembobot FFNN dan DLNN yang dilakukan dengan 10 replikasi, dimana model umum FFNN seperti pada Persamaan (3) sedangkan model umum DLNN seperti pada Persamaan (4).

e. Memilih model FFNN dan DLNN terbaik berdasarkan nilai RMSEP terkecil.

f. Melakukan peramalan dengan model FFNN dan DDNN terbaik.

Proses FFNN dan DLNN dapat digambarkan pada Lampiran 2 dan 3.

4. Melakukan pemodelan hybrid ARIMAX-FFNN (selanjutnya dinotasikan M-4) dan ARIMAX-DLNN (selanjutnya dinotasikan M-5) sebagai berikut:

a. Menentukan variabel input dengan minimal dua skenario, sebagai berikut:

1. Input layer terdiri dari komponen model ARIMAX terbaik seperti pada Langkah 2.
2. Input layer terdiri dari orde AR dari komponen $\hat{N}_{t}$ pada model ARIMAX terbaik. Jika terdapat orde MA maka diabaikan.

3. Jika tidak terdapat orde AR dari komponen $\hat{N}_{t}$ pada model ARIMAX terbaik ( $p=0)$, maka menggunakan lag PACF signifikan pada residual ARIMAX.

b. Melakukan preprocessing pada jumlah penumpang dan barang menggunakan normalisasi $[0,1]$.

c. Menentukan banyaknya neuron, yaitu dari 1 hingga 10 neuron pada masing-masing hidden layer.

d. Melakukan estimasi parameter untuk pembobot, yang dilakukan dengan 10 replikasi, dimana model umum $\hat{Z}_{t}=\hat{L}_{t}+\hat{N}_{t}$. dengan $\hat{L}_{t}$ merupakan model ARIMAX terbaik, sedangkan $\hat{N}_{t}$ untuk model hybrid ARIMAXFFNN serta hybrid ARIMAX-DLNN.

e. Memilih model hybrid terbaik berdasarkan nilai RMSEP terkecil.

f. Melakukan peramalan dengan model hybrid terbaik. Proses hybrid ARIMAX-FFNN dan ARIMAX-DLNN dapat digambarkan pada Lampiran 4 dan 5.

\section{ANALISIS DAN PEMBAHASAN}

\section{A. Karakteristik Data}

Pergerakan penumpang dan barang di Bandar Udara Internasional Juanda dapat dilihat pada Tabel 2.

\begin{tabular}{crrrr}
\multicolumn{5}{c}{ Tabel 2. Karakteristik Penumpang dan Barang } \\
\hline Variabel & Mean & $\begin{array}{c}\text { St. } \\
\text { Deviasi }\end{array}$ & Minimum & Maksimum \\
\hline$Z_{1}$ & 400160 & 184114 & 74986 & 889548 \\
$Z_{2}$ & 47946 & 21195 & 12131 & 107000 \\
$Z_{3}$ & 2796 & 1090 & 822 & 5204 \\
$Z_{4}$ & 680 & 196 & 200 & 1104 \\
$Z_{5}$ & 35109 & 21946 & 9697 & 132579 \\
$Z_{6}$ & 34092 & 17867 & 9047 & 101912 \\
$Z_{7}$ & 592055 & 225715 & 157561 & 1209631 \\
$Z_{8}$ & 641930 & 231004 & 284258 & 1330792 \\
\hline
\end{tabular}

Tabel 2 menunjukkan sebagian besar keberangkatan penumpang dan jumlah barang yang dimuat di Bandar Udara Internasional Juanda terjadi pada penerbangan domestik. Sedangkan di Pelabuhan Tanjung Perak, pergerakan keberangkatan dan kedatangan penumpang dalam negeri cenderung sama, hal yang sama terjadi pada jumlah barang.

\section{B. Pemodelan Jumlah Penumpang dan Barang}

Pemodelan jumlah penumpang keberangkatan domestik di Bandar Udara Internasional Juanda dengan membandingkan 5 metode sebagai berikut:

1. Pemodelan ARIMAX

Tahap pertama pemodelan ARIMAX adalah data dimodelkan dengan model regresi time series. Kemudian residual dari pemodelan time series tersebut dimodelkan dengan ARIMAX berdasarkan pola ACF dan PACF. Model yang didapatkan yaitu model ARIMAX dengan komponen tren, musiman, variasi kalender, serta komponen noise yang mengikuti model ARIMA ([2,10,12,16,17,23,24 ,25],0,0). Parameter tersebut diestimasi menggunakan Maximum Likelihood (MLE) serta dilakukan pengujian signifikansi parameter menggunakan uji $t$. Parameter yang paling tidak signifikan dalam uji $t$ dengan taraf signifikan 0,1 dikeluarkan dari model satu-persatu. Asumsi white noise dan distribusi normal pada residual model ARIMAX 
telah terpenuhi. Model ARIMAX secara matematis dapat dituliskan sebagai berikut:

$$
\begin{aligned}
Z_{1, t}= & 70900,7+5032 t+194389,8 D_{1}-213082,8 D_{2}+177814 D_{3} \\
& -4578,7 D_{1} t-2828,2 D_{3} t-55367,5 M_{2}-17406,1 M_{3} \\
& -32717,2 M_{4}+38427,1 M_{7}-74467,4 L_{1(t-1)}-49801,6 L_{2(t-1)} \\
& -33661,2 L_{3(t)}-77920 L_{4(t)}+18745,7 L_{2(t+1)}+30347,1 L_{4(t+1)} \\
& +N_{1, t},
\end{aligned}
$$

dengan

$$
N_{1, t}=\frac{1}{\left(1+0,34 B^{2}-0,19 B^{10}+0,48 B^{12}-0,19 B^{16}-0,24 B^{17}+0,17 B^{23}-0,19 B^{24}-0,36 B^{25}\right)} \varepsilon_{1, t} .
$$

1. Pemodelan FFNN

Input layer terdiri dari komponen pada model ARIMAX, yaitu komponen tren, musiman, variasi kalender, serta komponen noise yang mengikuti model ARIMA ([2,10,12,16,17,23,24,25],0,0). Proses pemodelan FFNN menggunakan fungsi aktivasi sigmoid pada hidden layer dan fungsi aktivasi linier pada output layer. Berdasarkan nilai RMSEP terkecil, model FFNN terbaik yaitu FFNN $(24,2,1)$, dengan arsitektur seperti pada Gambar 3.

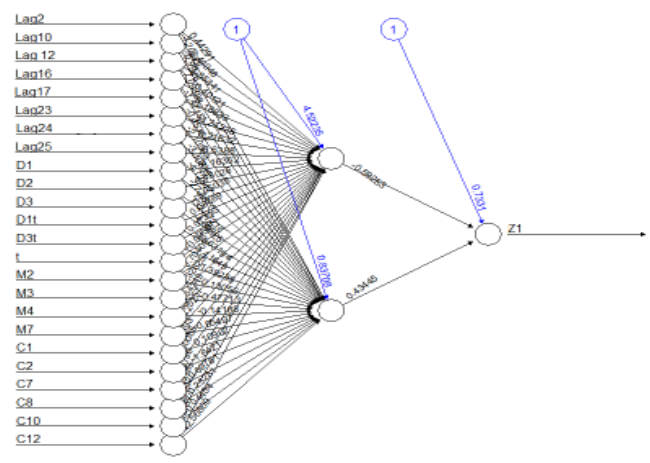

Gambar 3. Arsitektur FFNN $(24,2,1)$

Model FFNN $(24,2,1)$ secara matematis dapat ditulis sebagai berikut:

$$
\hat{Z}_{1,4}^{s}=0,73-0,59 f_{1}^{h}+0,43 f_{2}^{h},
$$

dengan:

$$
\begin{aligned}
f_{1}^{h}(.)= & \left(1+\exp \left(-\left(4,52+0,44 Z_{1, t-1}+2,45 Z_{1, t-10}+1,35 Z_{1, t-12}+0,4 Z_{1, t-16}\right.\right.\right. \\
& +1,19 Z_{1, t-17}-1,24 Z_{1, t-23}+0,22 Z_{1, t-24}-0,64 Z_{1, t-25}-0,1 t-4,16 D_{1} \\
& +4,48 D_{2}-4,05 D_{3}+0,09 D_{1} t+0,07 D_{3} t+0,7 M_{2}+0,33 M_{3} \\
& +0,34 M_{4}-0,25 M_{7}+1,19 L_{1(t-1)}+0,97 L_{2(t-1)}+1,23 L_{3(t)} \\
& \left.\left.\left.-0,35 L_{4(t)}-0,04 L_{2(t-1)}-0,03 L_{4(t-1)}\right)\right)\right)^{-1}, \\
f_{2}^{h}(.)= & \left(1+\exp \left(-\left(0,84+3,21 Z_{1, t-1}+0,99 Z_{1, t-10}+7,09 Z_{1, t-12}-1,47 Z_{1, t-16}\right.\right.\right. \\
& -0,45 Z_{1, t-17}-2,11 Z_{1, t-23}-2,11 Z_{1, t-24}-4,73 Z_{1, t-25}-1,39 t \\
& -27,39 D_{1}+132,37 D_{2}-4,69 D_{3}-12,63 D_{1} t+1,42 D_{3} t-0,13 M_{2} \\
& -0,48 M_{3}-0,14 M_{4}+0,65 M_{7}+0,11 L_{1(t-1)}-1,64 L_{2(t-1)}+0,69 L_{3(t)} \\
& \left.\left.\left.-0,25 L_{4(t)}-0,04 L_{2(t-1)}+42,57 L_{4(t-1)}\right)\right)\right)^{-1} .
\end{aligned}
$$

3. Pemodelan hybrid ARIMAX-FFNN

Terdapat dua level dalam pemodelan hybrid ARIMAXFFNN. Level pertama yaitu pemodelan ARIMAX yang telah dilakukan. Level kedua memodelkan residual dari model ARIMAX dengan FFNN. Pemodelan bertujuan untuk menangkap komponen nonlinier yang dianggap masih terdapat dalam residual model ARIMAX tersebut. Terdapat dua skenario untuk input dari model hybrid ARIMAX-FFNN seperti yang dijelaskan pada Langkah 4 di Langkah Analisis. Skenario pertama didapatkan model hybrid ARIMAX-FFNN (24,1,1), sedangkan skenario kedua didapatkan model hybrid ARIMAX-FFNN $(8,8,1)$. Berdasarkan nilai RMSEP terkecil, model hybrid
ARIMAX-FFNN terbaik dengan komposisi neuron $(8,8,1)$ dan secara matematis sebagai berikut:

$$
Z_{1, t}=\hat{L}_{1, t}^{(1)}+\hat{N}_{1, t}^{(2)}
$$

dimana $\hat{L}_{1, t}^{(1)}$ merupakan model ARIMAX dan $\hat{N}_{1, t}^{(2)}$ sebagai berikut:

$$
\begin{aligned}
\hat{N}_{1, t}= & -0,04-3,23 f_{1}^{h}+0,22 f_{2}^{h}+3,28 f_{3}^{h}-1,18 f_{4}^{h} \\
& +0,48 f_{5}^{h}+4,33 f_{6}^{h}+0,6 f_{7}^{h}+2,08 f_{8}^{h},
\end{aligned}
$$

dengan:

$$
\begin{aligned}
f_{1}^{h}(.)= & \left(1+\exp \left(-\left(-0,57-2,75 Z_{1, t-1}+2,78 Z_{1, t-10}-0,53 Z_{1, t-12}\right.\right.\right. \\
& -1,18 Z_{1, t-16}+4.20 Z_{1, t-17}-1,44 Z_{1, t-23}-1,11 Z_{1, t-24} \\
& \left.\left.\left.-2,26 Z_{1, t-25}\right)\right)\right)^{-1} \\
f_{2}^{h}(.)= & \left(1+\exp \left(-\left(-11,62+46,76 Z_{1, t-1}+17,09 Z_{1, t-10}\right.\right.\right. \\
& -37,33 Z_{1, t-12}+18,09 Z_{1, t-16}-11,20 Z_{1, t-17}-11,24 Z_{1, t-23} \\
& \left.\left.\left.+1,75 Z_{1, t-24}-4,40 Z_{1, t-25}\right)\right)\right)^{-1} \\
f_{3}^{h}(.)= & \left(1+\exp \left(-\left(1,61-1,63 Z_{1, t-1}-1,29 Z_{1, t-10}-1,29 Z_{1, t-12}\right.\right.\right. \\
& -0,77 Z_{1, t-16}-0,33 Z_{1, t-17}-1,89 Z_{1, t-23}+0,79 Z_{1, t-24} \\
& \left.\left.\left.-0,96 Z_{1, t-25}\right)\right)\right)^{-1} \\
f_{4}^{h}(.)= & \left(1+\exp \left(-\left(-0,62+1,81 Z_{1, t-1}-1,38 Z_{1, t-10}+3,51 Z_{1, t-12}\right.\right.\right. \\
& +8,06 Z_{1, t-16}-5,25 Z_{1, t-17}-7,93 Z_{1, t-23}+18,68 Z_{1, t-24} \\
& \left.\left.\left.+2,85 Z_{1, t-25}\right)\right)\right)^{-1}, \\
f_{5}^{h}(.)= & \left(1+\exp \left(-\left(0,95-27,46 Z_{1, t-1}+4,38 Z_{1, t-10}+0,08 Z_{1, t-12}\right.\right.\right. \\
& -15,55 Z_{1, t-16}+7,14 Z_{1, t-17}+18,38 Z_{1, t-23}+5,39 Z_{1, t-24} \\
& \left.\left.\left.+28,66 Z_{1, t-25}\right)\right)\right)^{-1}, \\
f_{6}^{h}(.)= & \left(1+\exp \left(-\left(-1,78+0,65 Z_{1, t-1}-0,92 Z_{1, t-10}-5,15 Z_{1, t-12}\right.\right.\right. \\
& +5,12 Z_{1, t-16}+2,73 Z_{1, t-17}-3,72 Z_{1, t-23}+0,72 Z_{1, t-24} \\
& \left.\left.\left.-7,26 Z_{1, t-25}\right)\right)\right)^{-1}, \\
f_{7}^{h}(.)= & \left(1+\exp \left(-\left(-2,09+18,05 Z_{1, t-1}-5,90 Z_{1, t-10}+28,46 Z_{1, t-12}\right.\right.\right. \\
& -17,32 Z_{1, t-16}-1,361 Z_{1, t-17}+22,71 Z_{1, t-23}-22,89 Z_{1, t-24} \\
& \left.\left.\left.+6,69 Z_{1, t-25}\right)\right)\right)^{-1}, \\
f_{8}^{h}(.)= & \left(1+\exp \left(-\left(-0,04-3,23 Z_{1, t-1}+0,22 Z_{1, t-10}+3,28 Z_{1, t-12}\right.\right.\right. \\
& -1,18 Z_{1, t-16}+0,48 Z_{1, t-17}+4,33 Z_{1, t-23}+0,60 Z_{1, t-24} \\
+ & \left.\left.\left.2,08 Z_{1, t-25}\right)\right)\right)^{-1} .
\end{aligned}
$$

\section{Pemodelan DLNN}

Proses pemodelan DLNN sama dengan proses pemodelan FFNN. Perbedaannya adalah pada jumlah hidden layer, yaitu sebayak dua. Berdasarkan nilai RMSEP terkecil, model DLNN terbaik yaitu DLNN $(24,2,1,1)$ dengan arsitektur model dapat dilihat pada Gambar 4.

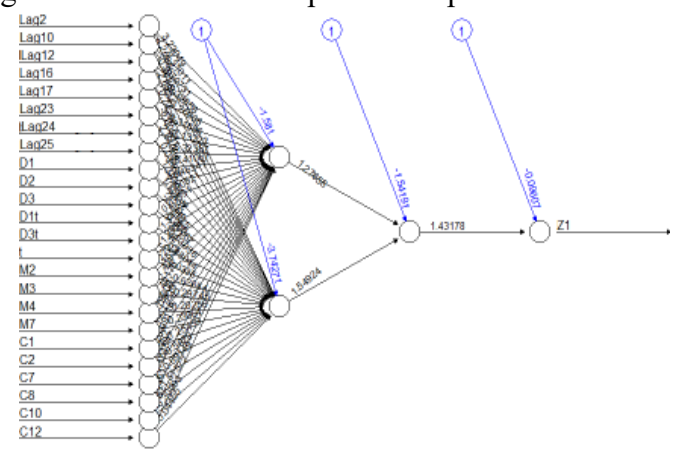

Gambar 4. Arsitektur DLNN $(24,2,1,1)$

Model DLNN $(24,2,1,1)$ secara matematis dapat ditulis sebagai berikut:

$$
\hat{Z}_{1, t}=-0,10+1,43 f^{h_{2}},
$$

dengan:

$f^{h_{2}}()=.\left(1+\exp \left(-\left(-5,3+1,28 f_{1}^{h}+1,55 f_{2}^{h}\right)\right)\right)^{-1}$, 


$$
\begin{aligned}
& f^{\prime h 1}(.)=\left(1+\exp \left(-\left(-1,58+3,23 Z_{1,-1}-2,31 Z_{1,-10}+3,71 Z_{1,-12}-2,33 Z_{1,-10}\right.\right.\right. \\
& -3,27 Z_{1,-17}+0,32 Z_{1,-23}-2,13 Z_{1,-24}-5,32 Z_{1,-25}-1,29 t+15,41 D \\
& +15,46 D_{2}-3,01 D_{3}+0,98 D_{1} t+1,34 D_{3} t-220,76 M_{2}-1,42 M_{3} \\
& -1,40 M_{4}+1,80 M_{7}-219,78 L_{1(t-1)}-220,99 L_{2(t-1)}-1,65 L_{3(t)} \\
& \left.\left.\left.-220,16 L_{4(\ell)}+0,28 L_{2(t-1)}+2,07 L_{4((-1))}\right)\right)\right)^{-1}, \\
& f_{2}^{h 1}(.)=\left(1+\exp \left(-\left(-3,74+2,21 Z_{1,-1-1}-0,47 Z_{1,-1-10}+2,64 Z_{1,-12}+0,74 Z_{1,-16}\right.\right.\right. \\
& -0,01 Z_{1,-17}+2,64 Z_{1,-23}+0,03 Z_{1,-24}+1,38 Z_{1,-25}+0,03 t+1,12 D_{t} \\
& -2,29 D_{2}-0,30 D_{3}-0,04 D_{t} t+0,98 D_{3} t-0,63 M_{2}-0,30 M_{2} \\
& -0,20 M_{4}+0,24 M_{7}-1,25 L_{t(t(-))}-0,56 L_{2(t(-))}-0,69 L_{3(t)}-1,52 L_{4(t)} \\
& \left.\left.\left.+0,30 L_{2(1-1)}-0,04 L_{4(L(-))}\right)\right)\right)^{-1} .
\end{aligned}
$$

5. Pemodelan hybrid ARIMAX-DLNN

Proses pemodelan hybrid ARIMAX-DLNN sama dengan proses pemodelan hybrid ARIMAX-FFNN. Perbedaannya adalah pada jumlah hidden layer sebayak dua. Berdasarkan nilai RMSEP terkecil, model terbaik yaitu hybrid ARIMAX-DLNN $(8,10,3,1)$, secara matematis model dapat dilihat pada Lampiran 1. Proses yang sama dilakukan pada 7 variabel lainnya dengan membandingkan 5 metode. Model terbaik untuk tiap variabel dapat dilihat pada Tabel 3 .

Tabel 3. Model Terbaik

\begin{tabular}{clrr}
\hline Variabel & Model Terbaik & \multicolumn{1}{c}{ RMSEP } & MAPEP \\
\hline$Z_{1, t}$ & M-4 $(24,2,1,1)$ & 48859,58 & 5,34 \\
$Z_{2, t}$ & M-4 $(54,10,3,1)$ & 5669,33 & 5,67 \\
$Z_{3, t}$ & M-4 $(26,9,3,1)$ & 391,28 & 9,14 \\
$Z_{4, t}$ & M-4 $(18,3,7,1)$ & 94,83 & 8,11 \\
$Z_{5, t}$ & M-4 $(21,7,1,1)$ & 4219,44 & 17,51 \\
$Z_{6, t}$ & M-4 $(24,2,3,1)$ & 5993,81 & 28,31 \\
$Z_{7, t}$ & M-5 $(8,10,6,1)$ & 211411,33 & 27,19 \\
$Z_{8, t}$ & M-4 (12,5,9,1) & 47833,56 & 9,12 \\
\hline
\end{tabular}

Time series plot perbandingan nilai ramalan dan data asli dapat dilihat pada Gambar 5 hingga Gambar 8. Gambar pada sisi kiri merupakan plot antara data training dan fits, sedangkan sisi kanan plot antara data testing dan nilai ramalan. Gambar 5 secara urut menunjukkan time series plot perbandingan untuk jumlah penumpang di Bandar Udara Internasional Juanda. Secara keseluruhan, hasil peramalan mengikuti pola data pada data training dan testing.
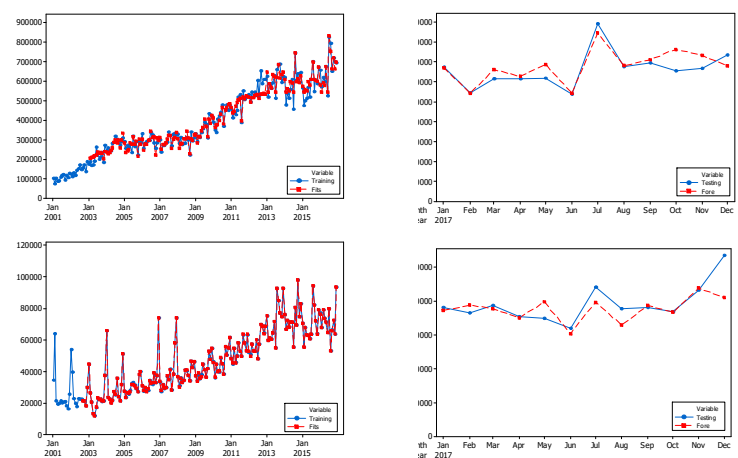

Gambar 5. Plot Time Series Model Terbaik Jumlah Penumpang di Bandar Udara Internasional Juanda

Gambar 6 secara urut menunjukkan time series plot perbandingan untuk jumlah barang di Bandar Udara Internasional Juanda. Secara keseluruhan, hasil peramalan mengikuti pola data pada data training, sedangkan pada data testing cenderung kurang mengikuti pola data asli.
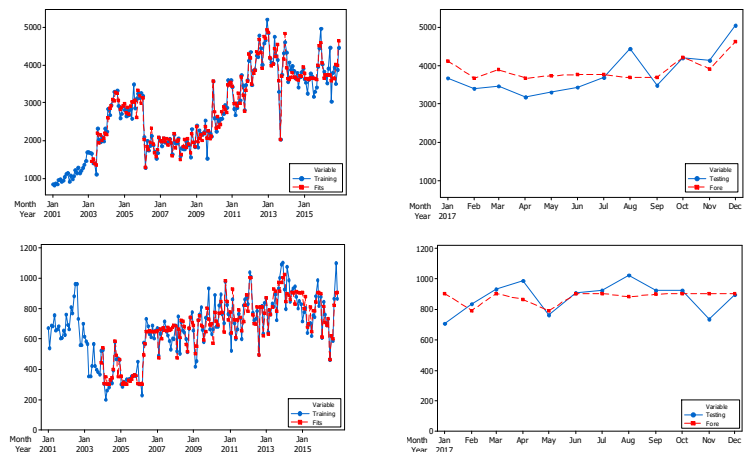
Gambar 6. Plot Time Series Model Terbaik Jumlah Barang di Bandar
Udara Internasional Juanda

Gambar 7 secara urut menunjukkan time series plot perbandingan untuk jumlah penumpang di Pelabuhan Tanjung Perak. Secara keseluruhan, hasil peramalan sangat mirip dan tidak berbeda jauh dari data testing. Oleh karena itu pemodelan dilakukan dengan tepat.
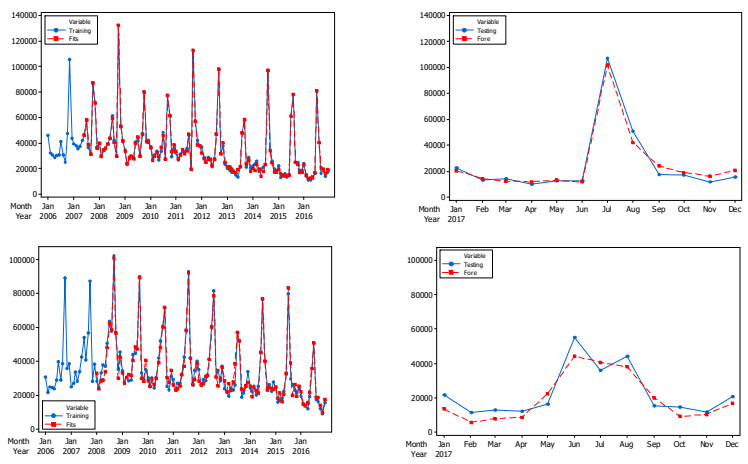

Gambar 7. Plot Time Series Model Terbaik Jumlah Penumpang di Pelabuhan Tanjung Perak

Gambar 8 secara urut menunjukkan time series plot perbandingan untuk jumlah barang di Pelabuhan Tanjung Perak. Secara keseluruhan, hasil peramalan cenderung mengikuti pola data.
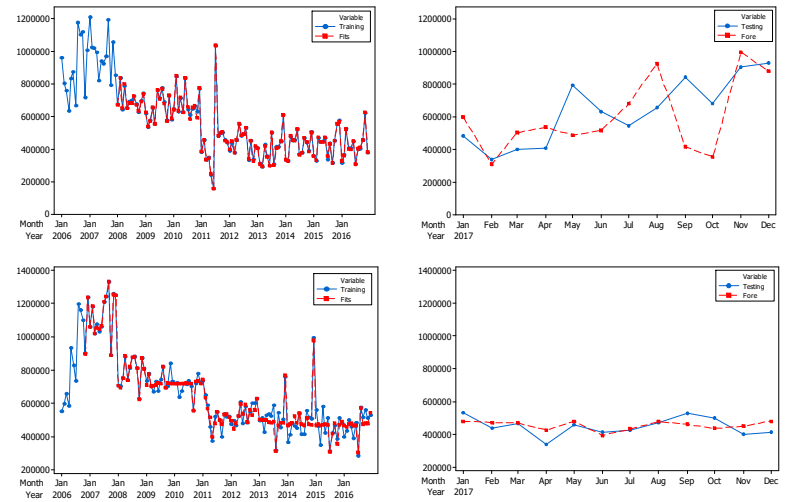

Gambar 8. Plot Time Series Model Terbaik Jumlah Barang di Pelabuhan Tanjung Perak

\section{Perbandingan Pemodelan ARIMAX, FFNN, DLNN} serta Hybrid

Rasio kriteria RMSE, RMSEP, MAPE dan MAPEP model nonlinier terhadap model ARIMAX dapat dilhat pada Gambar 9. 

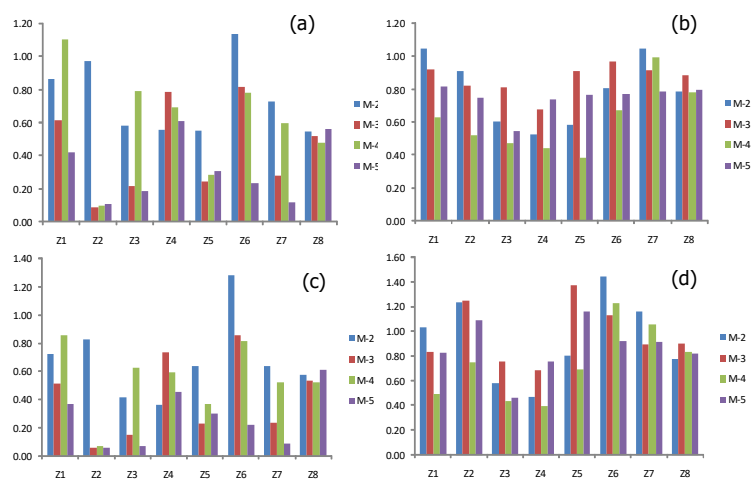

Gambar 9. Rasio RMSE (a), RMSEP (b), MAPE (c), dan MAPEP (d) Terhadap ARIMAX

Rasio RMSE dan MAPE menunjukkan performa model FFNN, DLNN dan hybrid lebih baik dibandingkan ARIMAX dalam memodelkan jumlah penumpang dan barang. Hal tersebut dapat dilihat dari nilai rasio yang secara umum kurang dari $100 \%$, yang berarti nilai RMSE dan MAPE model nonlinier lebih kecil dibandingkan model ARIMAX. Namun hal tersebut tidak selalu terjadi, seperti penelitian Makridakis dkk. dalam Kompetisi M3 yang menyebutkan bahwa model kompleks tidak selalu memberikan akurasi ramalan yang lebih baik [10]. Secara umum model hybrid ARIMAX-DLNN menghasilkan nilai kesalahan peramalan terkecil untuk data training. Hal ini sesuai dengan penelitian Makridakis dkk. dalam Kompetisi M4 yang menyatakan bahwa model hybrid dan kombinasi merupakan model dengan akurasi tertinggi dibandingkan dengan Machine Learning (ML) dan model klasik [11].

Rasio RMSEP dan MAPEP menunjukkan akurasi dari 4 model kompleks yang tidak selalu lebih baik dibandingkan model ARIMAX dalam menghasilkan ramalan jumlah penumpang dan barang. Namun model DLNN mampu menghasilkan akurasi terbaik pada 7 variabel, dan model hybrid ARIMAX-DLNN pada 1 variabel. Hal tersebut sesuai dengan penelitian He yang menyatakan bahwa deep learning mampu mereduksi kesalahan ramalan dari model klasik [8]. Pemodelan DLNN dalam kasus ini bagus dalam meramalkan dengan catatan inputnya mengikuti komponen model klasik, dalam penelitian ini model ARIMAX, sehingga model statistik membantu dalam menentukan input DLNN.

Nilai perbandingan RMSEP dari kelima model dengan panjang periode ramalan sebanyak 3, 6, 9 dan 12 bulan dapat dilihat pada Gambar 10 dan Gambar 11. Panjangnya periode ramalan yang digunakan dapat menghasilkan nilai akurasi yang berbeda. Perbandingan akurasi dengan periode ramalan yang berbeda digunakan untuk melihat kemampuan model dalam menghasilkan ramalan dengan periode yang beragam.

Gambar 10 menunjukkan model DLNN, sebagai model terbaik pada jumlah penumpang dan barang di Bandar Udara Internasional Juanda, hanya konsisten memiliki akurasi yang baik pada $Z_{1}$ dan $Z_{4}$. Hasil yang tidak konsisten terjadi pada $Z_{2}$ dan $Z_{3}$, dimana model terbaik dapat berbeda tergantung dari panjang periode ramalan. Pada variabel $Z_{2}$ menggambarkan jika periode ramalan semakin panjang maka nilai kesalahan semakin besar.
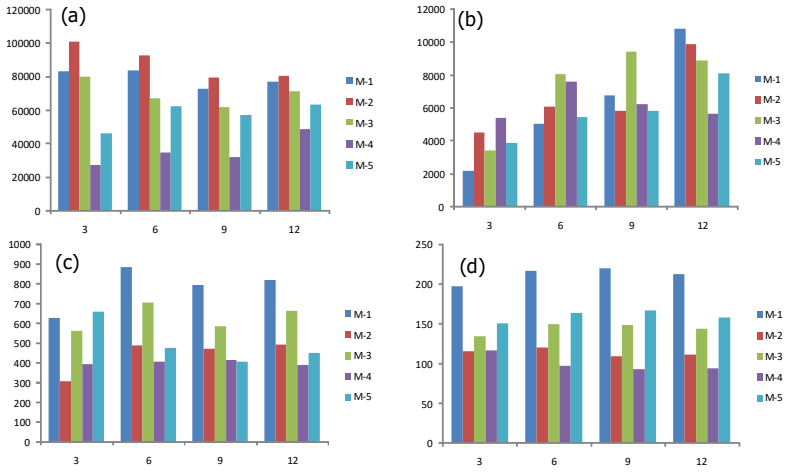

Gambar 10. Perbandingan Nilai RMSEP dari 5 Model Pada $Z_{1}(a), Z_{2}($ b), $\mathrm{Z}_{3}$ (c), dan $\mathrm{Z}_{4}$ (d) di Bandar Udara Internasional Juanda
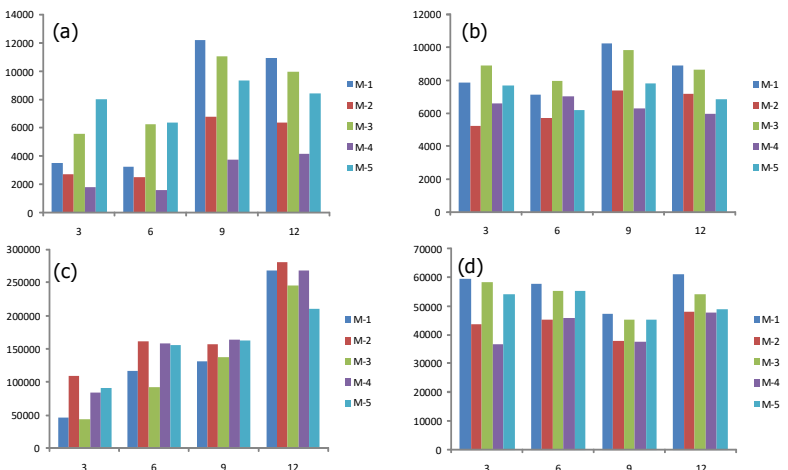

Gambar 11. Perbandingan Nilai RMSEP dari 5 Model Pada $Z_{6}(a), Z_{7}($ b), $Z_{8}$ (c), dan $Z_{9}(d)$ di Pelabuhan Tanjung Perak

Gambar 11 menunjukkan pada variabel $Z_{1}$ dan $Z_{3}$ memiliki kecenderungan jika periode ramalan semakin panjang maka nilai kesalahan semakin besar. Jika periode ramalan diperpanjang, maka akan menghasilkan nilai kesalahan yang besar atau akurasi ramalan yang kecil. Model DLNN dan hybrid ARIMAX-DLNN, sebagai model terbaik pada jumlah penumpang dan barang di Pelabuhan Tanjung Perak, hanya konsisten memiliki akurasi yang baik pada $Z_{6}$ sedangkan variabel lain tidak konsisten. Performansi tiap metode tergantung dari panjang periode ramalan. Hal tersebut dapat dilihat dari Gambar 10 dan 11 yang menunjukkan metode terbaik untuk meramalkan dapat berbeda tergantung dari panjang periode ramalan. Hal ini sesuai dengan hasil penelitian ke-4 dari Makridakis dkk. dalam Kompetisi M3 [10].

Tabel 4. Hasil Peramalan Jumlah Penunpang dan Barang di Bandar Udara Internasional Juanda Tahun 2018

\begin{tabular}{|c|c|c|c|c|}
\hline Bulan & $Z_{1, t}$ & $Z_{2, t}$ & $Z_{3, t}$ & $Z_{4, t}$ \\
\hline Januari & 686924 & 93487 & 4474 & 930 \\
\hline Februari & 669327 & 75827 & 3680 & 911 \\
\hline Maret & 582356 & 74517 & 3398 & 822 \\
\hline April & 636481 & 77909 & 3467 & 896 \\
\hline Mei & 645939 & 70313 & 3178 & 857 \\
\hline Juni & 629408 & 69690 & 3312 & 887 \\
\hline Juli & 498933 & 64054 & 3435 & 893 \\
\hline Agustus & 895077 & 88185 & 3698 & 909 \\
\hline September & 651546 & 74864 & 4439 & 915 \\
\hline Oktober & 703333 & 77260 & 3497 & 891 \\
\hline November & 729785 & 72671 & 4203 & 917 \\
\hline Desember & 692942 & 86277 & 4139 & 912 \\
\hline
\end{tabular}




\section{Peramalan Jumlah Penumpang dan Barang}

Hasil peramalan mulai Januari hingga Desember 2018 untuk jumlah penumpang dan barang di Bandar Udara Internasional Juanda dan Pelabuhan Tanjung Perak dapat dilihat pada Tabel 4 dan Tabel 5.

Tabel 5. Hasil Peramalan Jumlah Penunpang dan Barang di Pelabuhan Tanjung Perak Tahun 2018

\begin{tabular}{lrrrr}
\hline \multicolumn{1}{c}{ Bulan } & \multicolumn{1}{c}{$Z_{5, t}$} & $Z_{6, t}$ & \multicolumn{1}{c}{$Z_{7, t}$} & \multicolumn{1}{c}{$Z_{8, t}$} \\
\hline Januari & 16917 & 17534 & 842185 & 457825 \\
Februari & 19137 & 18010 & 838181 & 475079 \\
Maret & 11813 & 15038 & 1027700 & 445406 \\
April & 12346 & 11309 & 551474 & 478446 \\
Mei & 11517 & 11167 & 781798 & 412729 \\
Juni & 12756 & 17036 & 585802 & 456694 \\
Juli & 12699 & 54922 & 559729 & 426014 \\
Agustus & 107298 & 34221 & 588078 & 432372 \\
September & 49001 & 34947 & 450803 & 464453 \\
Oktober & 18971 & 24851 & 508099 & 470242 \\
November & 18374 & 13262 & 596822 & 452541 \\
Desember & 13463 & 15655 & 464722 & 440758 \\
\hline
\end{tabular}

\section{KESIMPULAN DAN SARAN}

Secara keseluruhan, model hybrid ARIMAX-DLNN memiliki performa yang baik dalam memodelkan dan menghasilkan akurasi yang besar pada data training. Namun performansi model tersebut tidak selalu baik ketika dibandingkan dengan data testing. Secara umum, model DLNN memiliki kemampuan yang baik dalam meramalkan data testing. Performansi tiap metode tergantung dari panjang periode ramalan. Hal ini sesuai dengan hasil penelitian ke-4 dari Makridakis dkk. dalam Kompetisi M3 [10]. Model terbaik untuk 8 variabel yang ada, terdapat 7 variabel dengan model terbaik yaitu model DLNN, sedangkan sisanya model hybrid ARIMAX-DLNN. Hasil ramalan menunjukkan jumlah penumpang dan barang di Juanda berfluktuasi tiap bulannya dan cenderung naik saat bulan Agustus 2018, jumlah penumpang Pelabuhan Tanjung Perak melonjak di bulan Lebaran. Saran untuk penelitian selanjutnya, dapat mencoba pemodelan Elman Neural Network yaitu Recurrent Neural Network (RNN) dimana orde MA dalam pemilihan input layer tidak diabaikan [16]. Pemodelan DLNN dan hybrid ARIMAXDLNN dapat mengurangi kesalahan dalam meramalkan, namun membutuhkan waktu yang cukup lama untuk running data. Sehingga waktu yang lama tersebut dapat menjadi pertimbangan dalam memilih metode tersebut.

\section{DAFTAR PUSTAKA}

[1] A. M. Senja, "Angkasa Pura I Layani 89,7 Juta Penumpang," 15 January 2018. [Online]. Available: http://www.travel.kompas.com. [Accessed 9 February 2018].

[2] A. Faizal, "Pelancong Asia Mulai Lirik Indonesia," 27 January 2018. [Online]. Available: http://www.ekonomi.kompas.com. [Accessed 23 February 2018].

[3] A. Tri, "Tantangan Menurunkan Dwelling Time di Pelabuhan Tanjung Perak," 29 January 2018. [Online]. Available: https://www.bisniskini.com. [Accessed 23 February 2018].

[4] A. M. Huda, H. Kuswanto and Suhartono, "Forecasting The Frequency of Domestic Air Passenger at Juanda Airport Using ARIMA and Transfer Function as a Basis For Future Development of Airport Scenario," Jurnal Tata Kota dan Daerah, pp. 21-26, 2014.

[5] G. P. Zhang, "Time Series Forecasting Using a Hybrid ARIMA and Neural Network Model. Neurocomputing," pp. 159-175, 2003.
[6] T. Hirata, T. Kuremoto, Obayashi, M. S. M. and K. Kobayashi, "Time Series Prediction Using DBN and ARIMA," in International Conference on Computer Application Technologies, 2015.

[7] L. Zhu, G. Zhu, L. Han and N. Wang, "The Application of Deep Learning in Airport Visibility Forecast," Atmospheric and Climate Sciences, pp. 314-322, 2017.

[8] W. He, "Load Forecasting via Deep Learning Networks," Procedia Computer Science, pp. 308-314, 2017.

[9] Y. Lv, Y. Duan, W. L. Z. Kang and F. Wang, "Traffic Flow Prediction With Big Data: A Deep Learning Approach," IEEE Transactions on Intelligent Transportation Systems, pp. 865-873, 2015.

[10] S. Makridakis and M. Hilbon, "The M-3 Competition: result, conclution, and implications," International Journal of Forecasting, pp. 451-476, 2000.

[11] S. Makridakis, E. Spiliotis and V. Assimakopoulos, "The M-4 Competition: Result, findings, conclusion and way forward," International Journal of Forecasting, 2018.

[12] J. D. Cryer and K. Chan, Time Series Analysis With Applications in R, Second Edition, New York: Springer, 2008.

[13] M. H. Lee, Suhartono and N. A. Hamzah, "Calendar Variation Model Based on ARIMAX Forecasting Sales Data with Ramadhan Effect.," in Regional Conference on Statistical Science, 2010.

[14] Suhartono, Feedforward Neural Network untuk Pemodelan Runtun Waktu., Yogyakarta: Disertasi Doktoral, Universitas Gajah Mada., 2007.

[15] W. W. S. Wei, Time Series Analysis, New York: Addison Wesley, 2006.

[16] N. D. Lewis, Deep Learning Made Easy With R: A Gentle Introduction for Data Science, AusCov, 2016. 


\section{LAMPIRAN}

Lampiran 1. Model hybrid ARIMAX-DLNN $(8,10,3,1)$.

$$
Z_{1, t}=\hat{L}_{1, t}^{(1)}+\hat{N}_{1, t}^{(2)}
$$

dimana $\hat{L}_{1, t}^{(1)}$ merupakan model ARIMAX dan $\hat{N}_{1, t}^{(2)}$ pada Persamaan (17).

dengan:

$$
\hat{N}_{1, t}=0,53+2,73 f_{1}^{h_{2}}-0,87 f_{2}^{h_{2}}-0,75 f_{3}^{h_{2}}
$$

$$
\begin{aligned}
& f_{1}^{h_{2}}(.)=\left(1+\exp \left(-\left(0,53+10,54 f_{1}^{h}+15,87 f_{2}^{h}-1,02 f_{3}^{h}-3,17 f_{4}^{h}\right.\right.\right. \\
& \left.\left.\left.-1,97 f_{5}^{h}-2,05 f_{6}^{h}-1,05 f_{7}^{h}-0,14 f_{8}^{h}-0,40 f_{9}^{h}+1,57 f_{10}^{h}\right)\right)\right)^{-1}, \\
& f_{2}^{h_{2}}(.)=\left(1+\exp \left(-\left(-0,34-19,82 f_{1}^{h}+140,43 f_{2}^{h}-2,08 f_{3}^{h}-14,00 f_{4}^{h}\right.\right.\right. \\
& -8,14 f_{5}^{h}-23,63 f_{6}^{h}-0,83 f_{7}^{h}+3,80 f_{8}^{h}+24,43 f_{9}^{h} \\
& \left.\left.\left.+11,01 f_{10}^{h}\right)\right)\right)^{-1} \text {, } \\
& f_{3}^{h_{2}}(.)=\left(1+\exp \left(-\left(-5,15+160,59 f_{1}^{h}-8,55 f_{2}^{h}-10,10 f_{3}^{h}+21,09 f_{4}^{h}\right.\right.\right. \\
& +6,33 f_{5}^{h}+198,14 f_{6}^{h}+91,48 f_{7}^{h}-14,53 f_{8}^{h}+31,90 f_{9}^{h} \\
& \left.\left.\left.-14,42 f_{10}^{h}\right)\right)\right)^{-1} \text {, } \\
& f_{1}^{h_{1}}(.)=\left(1+\exp \left(-\left(-1,03-1,03 Z_{1, t-1}-1,32 Z_{1, t-10}+0,44 Z_{1, t-12}-0,57 Z_{1, t-16}\right.\right.\right. \\
& \left.\left.\left.-2,17 Z_{1, t-17}+0,05 Z_{1, t-23}+1,13 Z_{1, t-24}-0,08 Z_{1, t-25}\right)\right)\right)^{-1}, \\
& f_{2}^{h l}(.)=\left(1+\exp \left(-\left(-0,25+2,03 Z_{1, t-1}-4,85 Z_{1, t-10}-9,17 Z_{1, t-12}+3,75 Z_{1, t-16}\right.\right.\right. \\
& \left.\left.\left.-1,06 Z_{1, t-17}-4,71 Z_{1, t-23}+6,36 Z_{1, t-24}-6,23 Z_{1, t-25}\right)\right)\right)^{-1}, \\
& f_{3}^{h_{11}}(.)=\left(1+\exp \left(-\left(1,57-14,67 Z_{1, t-1}+12,25 Z_{1, t-10}+1,39 Z_{1, t-12}+11,40 Z_{1, t-16}\right.\right.\right. \\
& \left.\left.\left.-11,68 Z_{1, t-17}-5,63 Z_{1, t-23}+3,58 Z_{1, t-24}-6,75 Z_{1, t-25}\right)\right)\right)^{-1} \text {, } \\
& f_{4}^{h_{1}}(.)=\left(1+\exp \left(-\left(0,20+0,22 Z_{1, t-1}+2,27 Z_{1, t-10}+0,72 Z_{1, t-12}-1,40 Z_{1, t-16}\right.\right.\right. \\
& \left.\left.\left.-4,94 Z_{1, t-17}+0,40 Z_{1, t-23}+1,97 Z_{1, t-24}-3,02 Z_{1, t-25}\right)\right)\right)^{-1}, \\
& f_{5}^{h_{1}}(.)=\left(1+\exp \left(-\left(-2,76-4,62 Z_{1, t-1}-3,17 Z_{1, t-10}-5,05 Z_{1, t-12}+3,67 Z_{1, t-16}\right.\right.\right. \\
& \left.\left.\left.-3,04 Z_{1, t-17}-2,83 Z_{1, t-23}+11,97 Z_{1, t-24}+4,06 Z_{1, t-25}\right)\right)\right)^{-1}, \\
& f_{6}^{h_{1}}(.)=\left(1+\exp \left(-\left(-0,88-3,52 Z_{1, t-1}+3,96 Z_{1, t-10}-1,95 Z_{1, t-12}-3,30 Z_{1, t-16}\right.\right.\right. \\
& \left.\left.\left.+5,13 Z_{1, t-17}-3,15 Z_{1, t-23}-0,23 Z_{1, t-24}-1,95 Z_{1, t-25}\right)\right)\right)^{-1}, \\
& f_{7}^{h_{1}}(.)=\left(1+\exp \left(-\left(-0,86+7,11 Z_{1, t-1}-4,76 Z_{1, t-10}+3,95 Z_{1, t-12}+6,29 Z_{1, t-16}\right.\right.\right. \\
& \left.\left.\left.-9,32 Z_{1, t-17}-10,75 Z_{1, t-23}+0,08 Z_{1, t-24}+0,34 Z_{1, t-25}\right)\right)\right)^{-1}, \\
& f_{8}^{h_{1}}(.)=\left(1+\exp \left(-\left(-5,21+1,98 Z_{1, t-1}+1,13 Z_{1, t-10}+4,53 Z_{1, t-12}-3,21 Z_{1, t-16}\right.\right.\right. \\
& \left.\left.\left.+1,47 Z_{1, t-17}-0,38 Z_{1, t-23}+11,06 Z_{1, t-24}-2,66 Z_{1, t-25}\right)\right)\right)^{-1}, \\
& f_{9}^{h_{1}}(.)=\left(1+\exp \left(-\left(-0,34-1,84 Z_{1, t-1}-3,56 Z_{1, t-10}+0,50 Z_{1, t-12}-2,26 Z_{1, t-16}\right.\right.\right. \\
& \left.\left.\left.+1,58 Z_{1, t-17}+4,30 Z_{1, t-23}-4,13 Z_{1, t-24}+1,96 Z_{1, t-25}\right)\right)\right)^{-1}, \\
& f_{10}^{h_{1}}(.)=\left(1+\exp \left(-\left(-1,29-1,70 Z_{1, t-1}+4,24 Z_{1, t-10}-0,85 Z_{1, t-12}-1,44 Z_{1, t-16}\right.\right.\right. \\
& \left.\left.\left.-0,21 Z_{1, t-17}+0,62 Z_{1, t-23}-0,03 Z_{1, t-24}-0,80 Z_{1, t-25}\right)\right)\right)^{-1} \text {. }
\end{aligned}
$$


Lampiran 2. Proses FFNN

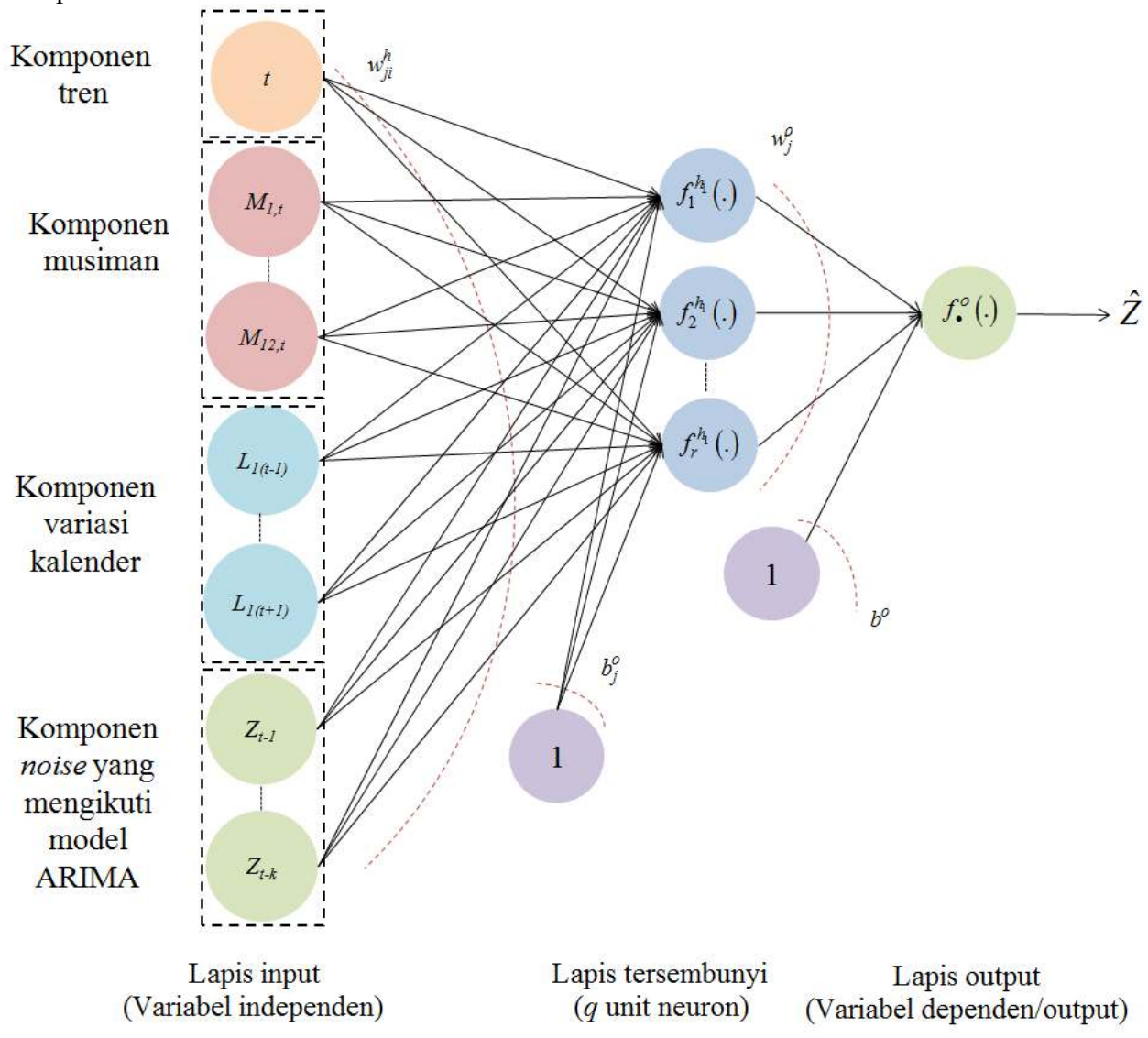

Lampiran 3. Proses DLNN

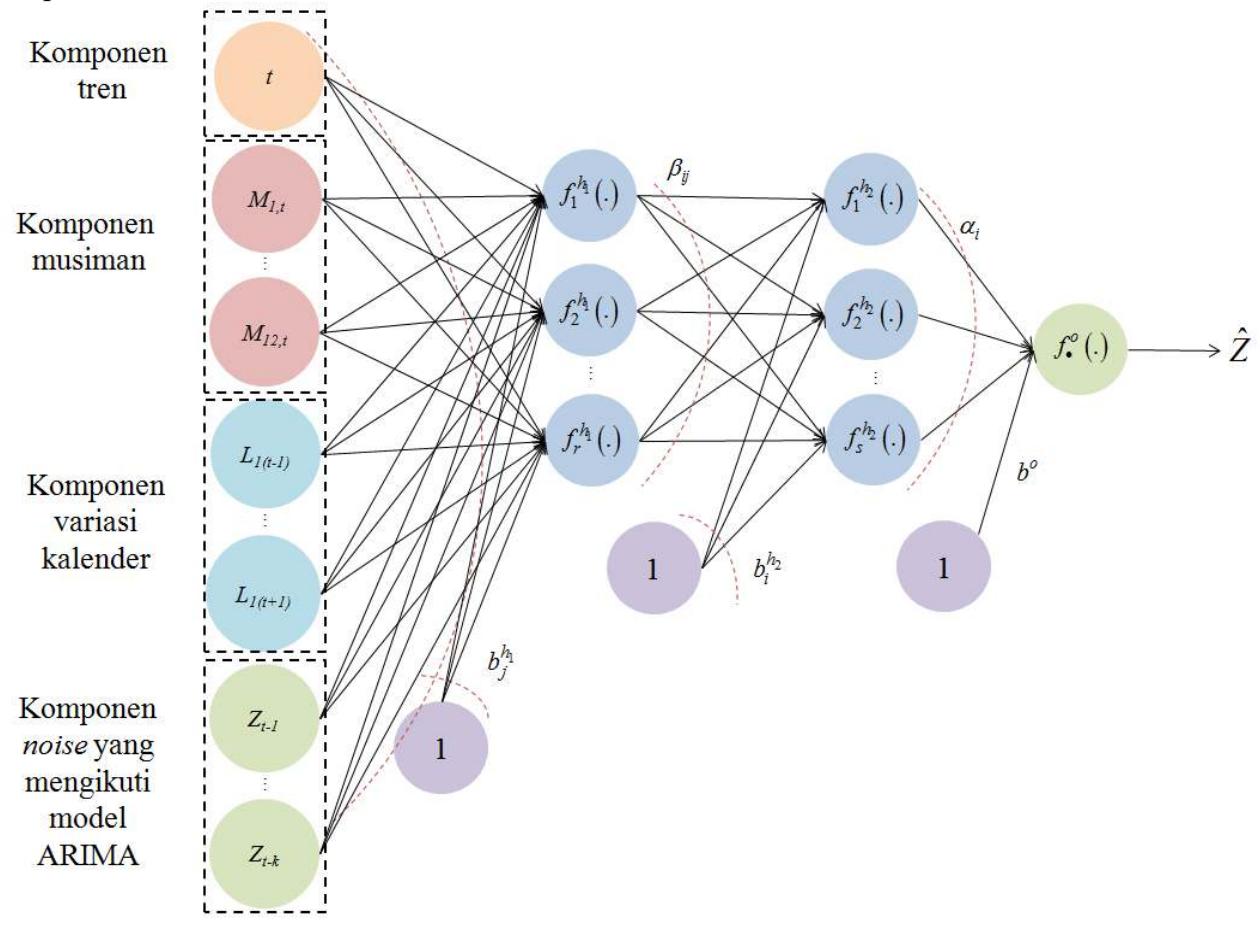


Lampiran 4. Proses hybrid ARIMAX-DLNN dengan Skenario Input Pertama

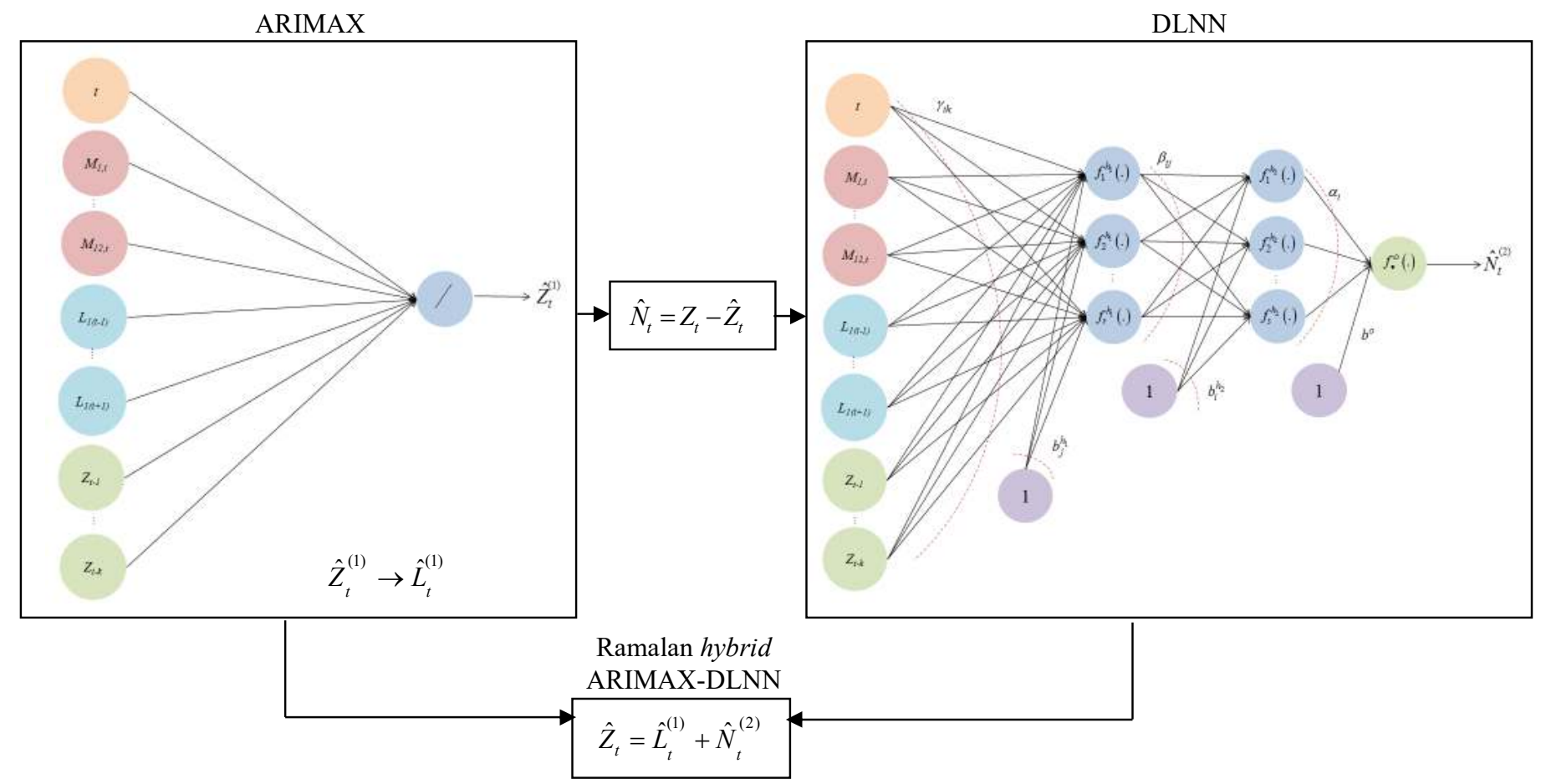

Lampiran 5. Proses hybrid ARIMAX-DLNN dengan Skenario Input Kedua

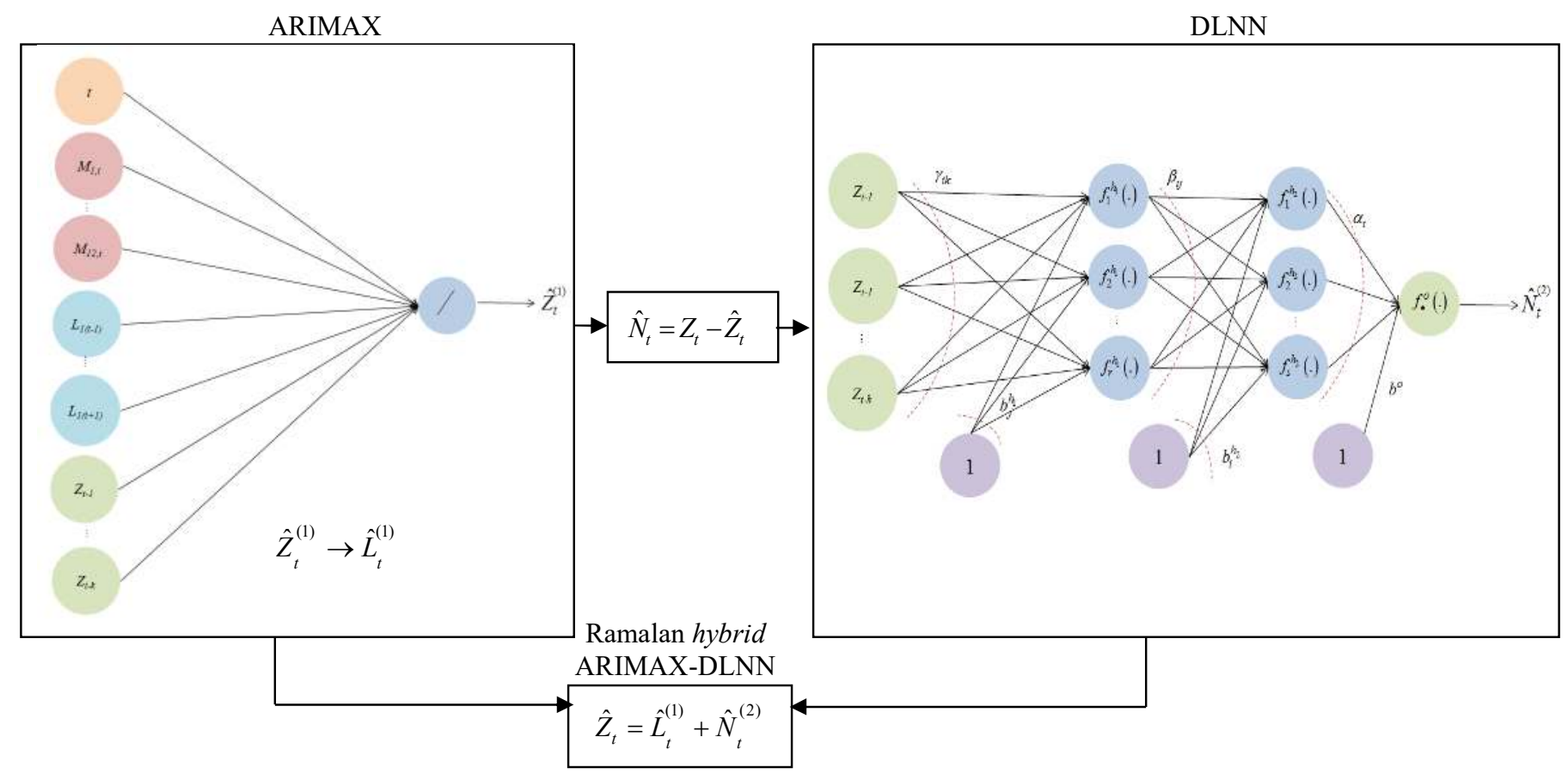

